\title{
Election 2015: closing the Aboriginal health gap
}

$\mathrm{T}$ he story of five-yearold Brody Meekis' death from strep throat in a remote First Nations community in Northwestern Ontario hit the national news and social media less than three weeks after the start of the federal election campaign on Aug. 2.

Brody, who lived in Sandy Lake, a fly-in community with a federal nursing station, died from a common infection that family doctors routinely and successfully treat with antibiotics. The little boy never saw a doctor, since none routinely staff the nursing station Health Canada operates on his reserve.

"The system failed my son," Brody's father, Fraser Meekis, told the Globe and Mail on Aug. 20.

The system fails many Aboriginal children - and adults. Brody's death and the death from strep throat of a little girl on the Pikangikum First Nation, are just two examples of the often fatal health care inequities experienced by indigenous Canadians.

"They're the sickest and the poorest people in Canada, in our own backyard," says Dr. Darlene Kitty, a family physician in Chiassibi, Que., and the president of the Indigenous Physicians Association of Canada.

Compared with non-indigenous Canadians, First Nations, Inuit and Métis people have higher rates of chronic diseases such as diabetes, tuberculosis and rickets. They have higher infant mortality rates and shorter lifespans, by five to seven years. First Nations' adults, for example, are more than twice as likely as other Canadians to die from avoidable causes (including diabetes, lung cancer, accidental injuries, drug and alcoholrelated causes and suicide), according to

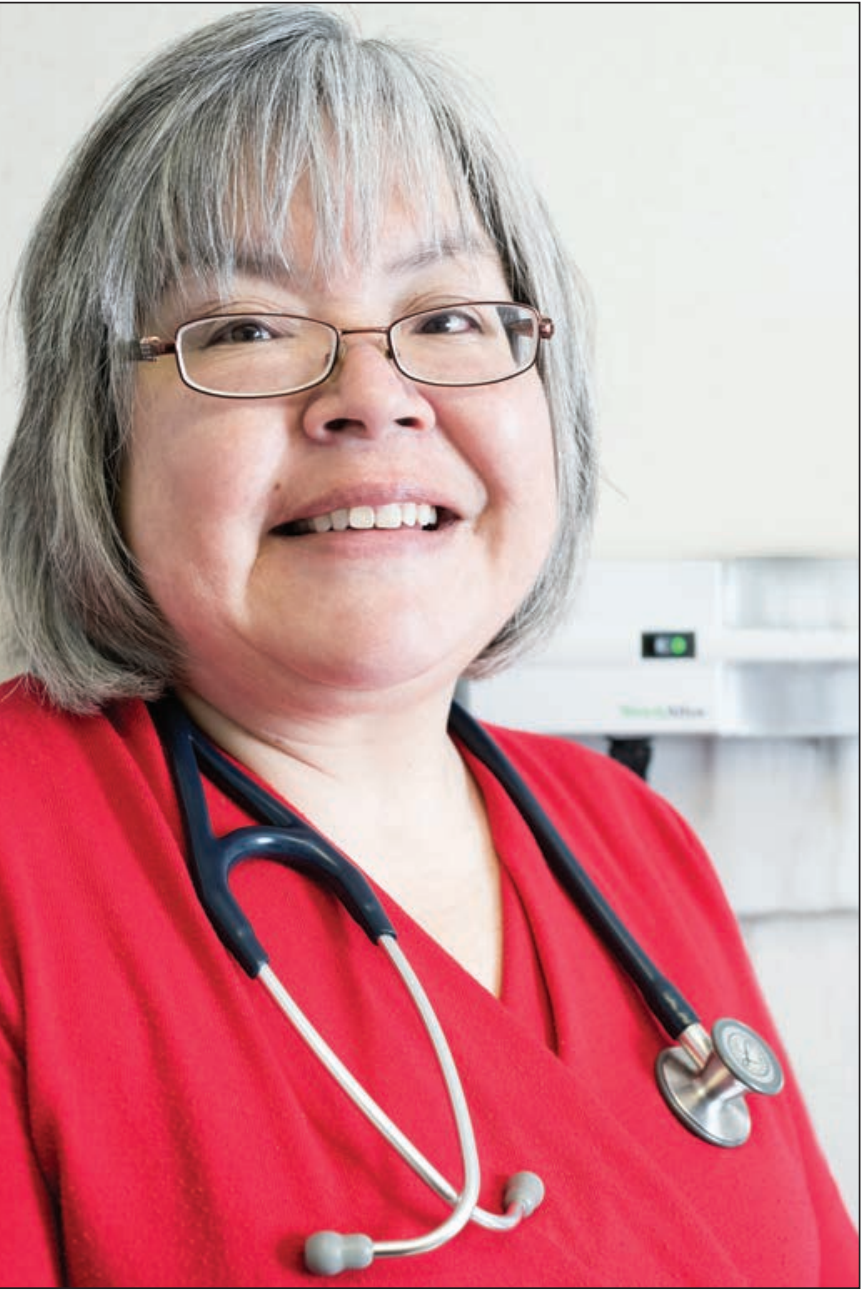

Aboriginal people are the "sickest and the poorest people in Canada," says Dr. Darlene Kitty, president of the Indigenous Physicians Association of Canada.

a benchmark Statistics Canada study published in August.

Indigenous Canadians also experience higher rates of domestic violence and sexual assault - as Nunavut Tunngavik Inc., the agency charged with securing Inuit economic, social and cultural well-being, points out in a 2014 report on the Nunavut Justice system.

"Women and children are the most vulnerable populations in the territory, experiencing physical and sexual violence at rates far above the rest of the country," the report states. "Compounding this problem is the lack of resources and support available for women and children who experience violence."

Despite these welldocumented disparities, Aboriginal health issues have not gained much traction during the federal election campaign, says Perry Bellegarde, national chief of the Assembly of First Nations (AFN).

"The gap is all around us, as First Nations people," says Bellegarde. "Half of our children live in poverty, which is more than double the national average. There are 40000 Aboriginal children and youth who live in foster care. There are 132 First Nations communities with boil water advisories."

Bellegarde wants all Canadians to ask how campaigning politicians plan to "close the gap." In a Sept. 2 document, the AFN calls on the next federal government to collaborate on a First Nations Health Plan that includes longterm investments in prevention, promotion and health services, and better access to culturally appropriate health human resources. The AFN is also asking for a First Nations Mental Wellness Continuum Framework.

Only public pressure will force political action, says Bellegarde. He applauds Liberal Leader Justin Trudeau's promise if elected to invest in reserve housing and infrastructure, and in First Nations education and training, as well as commitments by Trudeau and National Democratic Party Leader Tom Mulcair to hold an inquiry into missing and murdered indigenous women.

The Conservative Party has not yet committed to holding an inquiry, which is among the 94 recommendations of 
the Truth and Reconciliation Commission. It also recommends that the federal government set measurable goals to close the gaps in health outcomes, to establish healing centres, to increase the number of Aboriginal health care providers and to recognize Aboriginal healing practices, among other healthrelated recommendations.

The commission provided political parties with the chance to articulate their positions during the campaign, says Jeff Reading, the interim director of the new Waakebiness-Bryce Institute for Indige- nous Health at the University of Toronto's Dalla Lana School of Public Health. "Housing, water quality and education - these are the things that we know determine health, and we've known for a long time."

"Everything is tied to economics," points out Claudette Dumont-Smith, the executive director of the Native Women's Association of Canada and a registered nurse. "The burden of illness of Aboriginal people, women included, is costing the system a lot,".

Brody Meekis's death illustrates the most critical health issue Aboriginal Canadians face, says Bellegarde access to comparable health care. "That's all First Nations people are asking for." - Laura Eggertson, Ottawa, Ont.

In $C M A J$ 's election survey, the leaders of all five federal parties were asked what they would do to close to the gap. Look for their responses at cmaj.ca.

CMAJ 2015. DOI:10.1503/cmaj.109-5155 